The Effect of Dredging on the Water Quality and Fish and Crustacean Composition of the Lunawa Lagoon by

P.V. Ishastha Prasith Perera

Thesis submitted to the University of Sri Jayewardenepura for the award of the Degree of Master of Science in Fisheries and Aquatic Resource Management on May 2009. 
"The work described in this thesis was carried out by me under the supervision of Dr. Ajantha De Alwis and a report on this has not been submitted in whole or in part to any university or any other institution for another Degree".

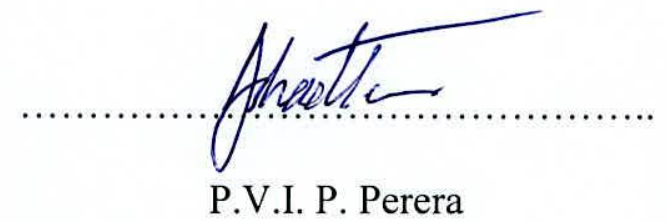


"I / we certify that the above statement made by the candidate is true and that this thesis is suitable for submission to the University for the purpose of evaluation"

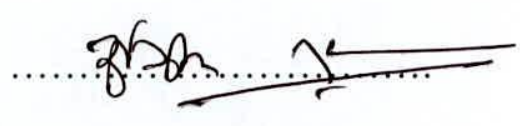

Dr.A.De Alwis

(Supervisor)

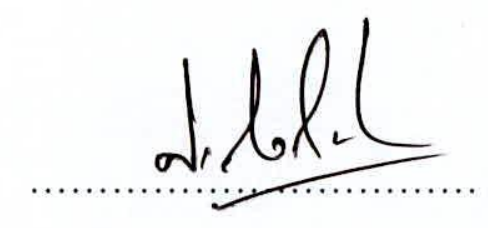

Dr. B.G.N. K. De Silva

(Head of Department)

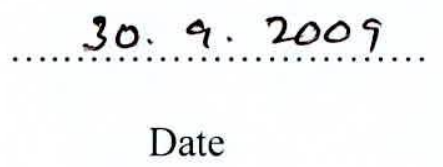


1. INTRODUCTION

1.1 Physical Features of Lunawa Lagoon 2

1.2 The Pollution Problem in Lunawa Lagoon 7

1.3 The Lunawa Environment Improvement and Development Project 10

1.4. OBJECTIVES

2. MATERIALS AND METHODS

$\begin{array}{lll}2.1 & \text { Analysis } & 15\end{array}$

3. RESULTS 16

3.1 Status of the Lagoon as a Whole Over 3 Defined Periods 16

$\begin{array}{ll}\text { 3.2 Comparison Between Sites } & 23\end{array}$

3.3 Other Sites Studied 35

3.4 Present Fish and Crustacean Composition $\quad 46$

$\begin{array}{lr}\text { 4. DISCUSSION } & 48\end{array}$

$\begin{array}{lr}\text { 5. CONCLUSION } & 60\end{array}$

6. REFERENCES

7. ANNEXURES

$\begin{array}{lll}\text { Annexure 1 Laboratory Tests } & 66\end{array}$

Annexure 2 Average values of the parameters monitored for the

Lunawa Lagoon before after and during dredging $\quad 76$

Annexure 3 Average values of the parameters monitored at 4 sites

in the Lunawa Lagoon before after and during dredging $\quad 77$

$\begin{array}{lll}\text { Annexure 4 Water Quality Standards } & 79\end{array}$

$\begin{array}{llr}\text { Annexure } 5 \text { Species Composition } & \mathbf{8 0}\end{array}$ 


\section{List of Tables}

Table 1: Fish and crustaceans found in Lunawa Lagoon prior to the pollution problem 6

Table 2: Coordinates of the sample sites

Table 3: Summary of fish and crustacean catches over a period of 4 months

Table 4: Average values for the Lunawa Lagoon as a whole

Table 5: Average values for Site L3 $\quad 77$

$\begin{array}{ll}\text { Table 6: Average values for Site L2 } & 77\end{array}$

$\begin{array}{lr}\text { Table 7: Average values for Site L1 } & \mathbf{7 8}\end{array}$

$\begin{array}{lr}\text { Table 8: Average values for Site N2 } & \mathbf{7 8}\end{array}$

Table 9: CEA proposed water quality standards/ CLASS II Water CATEGORY

04-Fish \& Aquatic Life

Table 10: Fish and crustacean catch in Lunawa Lagoon 


\section{List of Figures}

Fig 1: Lagoons and Estuaries of Sri Lanka $\quad 1$

Fig 2: Location of Lunawa Lagoon 3

Fig 3: The Bolgoda Basin 4

Fig 4: Sample Sites $\quad \mathbf{1 2}$

$\begin{array}{ll}\text { Fig 5: Variation of Air and Water Temperature } & 17\end{array}$

$\begin{array}{lr}\text { Fig 6: Variation of Water Depth } & 18\end{array}$

Fig 7: Variation of Electrical Conductivity and Salinity 19

Fig 8: Variation of BOD and Dissolved Oxygen $\quad \mathbf{2 0}$

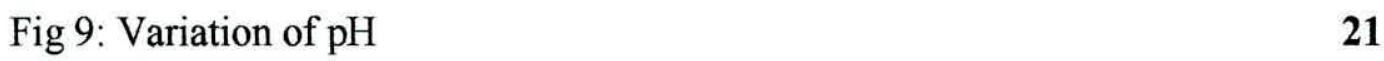

Fig 10: Variation of Transparency $\quad \mathbf{2 1}$

Fig 11: Variation of Phosphate and Nitrate $\quad 22$

Fig 12: Sampling Sites in the Lunawa Lagoon $\quad 23$

Fig 13: Comparison of Air and Water Temperature Between Sites 24

Fig 14: Comparison of Water Depth Between Sites 26

Fig 15: Comparison of Electrical Conductivity and Salinity Between Sites 27

Fig 16: Comparison of BOD and Dissolved Oxygen Between Sites 29

Fig 17: Comparison of $\mathrm{pH}$ Between Sites 31

Fig 18: Comparison of Transparency Between Sites 32

Fig 19: Comparison of Phosphate and Nitrate Between Sites 34

Fig 20: Air Temperature at Sites $\quad \mathbf{3 5}$

Fig 21: Water Temperature at Sites $\quad 36$ 
Fig 22: Water Depth at Sites

Fig 23: Electrical Conductivity at Sites $\quad 38$

Fig 24: Dissolved Oxygen at Sites

Fig 25: pH Levels at Sites $\quad \mathbf{4 0}$

Fig 26: Salinity Levels at Sites $\quad \mathbf{4 1}$

Fig 27: Transparency Levels at Sites $\quad 42$

Fig 28: BOD Levels at Sites $\quad 43$

Fig 29: Phosphate Phosphorus Levels at Sites 44

Fig 30: Nitrate Nitrogen Levels at Sites 45

Fig 31: Fish Catch and Fishing Effort Over a Period of 4 Months 47 


\section{Acknowledgements}

First and foremost I thank the Lord for the strength and wisdom granted to carry out this activity. All glory be to Him!

I would like to very specially thank my supervisor Dr. Ajantha De Alwis, whose continued guidance and correction enabled this research project to be a success. I would like to make special mention of her commitment towards this research study as amidst her busy schedules and challenging situations, she was always available to direct and guide me.

I would also like to thank Mr. Wijenayake and all the Laboratory Technicians, for extending their fullest support in carrying out the laboratory analyses of the project.

I would also like to thank Jehan Gamlathge for accompanying me during several visits to the lagoon. A special thank you to Mr. Piumsiri, the local fisherman who was always present with his canoe to take me to all the sampling locations and provided great support in obtaining data on daily fish catches.

I would also like to express my gratitude to my family who encouraged me right throughout the course of this study and especially my fiancé whose love and support right till the end enabled me to complete this research. My sincere thanks to all the friends and relatives whose prayers and support in various forms helped me immensely. 


\title{
The Effect of Dredging on the Water Quality and Fish and Crustacean
}

\section{Composition of the Lunawa Lagoon}

\section{P. V. Ishastha Prasith Perera}

\begin{abstract}
The Lunawa Lagoon situated a few kilometers south of Colombo was once a thriving fishing ground, which supported a significant fishery. Prior to the 1970's the lagoon provided good fish harvests to the fisher folk in the surrounding area. Industrialization of the surrounding areas with little environmental planning resulted in mass degradation of the lagoon over the years, resulting in highly polluted water, loss of species diversity and a total collapse of the fishery by the mid 1990's. In addition to this, the lagoon became a breeding ground for mosquitoes thus causing a health hazard and the stench from the dumping of industrial and domestic wastes made it an unsuitable residential area. In order to combat this problem and revive the lagoon, a massive project was undertaken in 2004, which involved dredging of the lagoon to remove accumulated waste sediments and to improve seawater exchange.
\end{abstract}

A research study was carried out to determine the present status of the lagoon in terms of its water quality and the fish and crustacean species present after the completion of the dredging activity. In comparison with the status of the lagoon just before the dredging activity and after, results of the study indicate a significant positive change with dissolved oxygen, $\mathrm{pH}$, Biochemical Oxygen Demand (BOD) and phosphate levels all improving to levels within the stipulated standards. Up to 7 species of fish along with 2 shrimp and $1 \mathrm{crab}$ species were identified. The types and numbers of species in 
the lagoon had improved distinctly and were now found to support a small-scale fishery. The depth of the lagoon had also increased fulfilling a major objective of the project. However, turbidity, electrical conductivity and salinity levels had not changed significantly, while nitrate levels had increased indicating the existence of continuing pollution. The levels though were not found to be immediately harmful, provided warning signs of a potential threat that needed to be addressed.

In order to safeguard the improvement of the lagoon achieved and enable further recovery, strict monitoring and management is necessary while special focus should be given to verify whether effluents discharged by industries are being treated according to the environmental regulations. Due regard to the environment and the lagoon in particular must be given by all relevant authorities in all future plans for the area especially in the industrial sector.

Overall, the effect of dredging on the water quality and fish and crustacean composition of the Lunawa Lagoon was found to be positive with a significant improvement observed. 


\section{INTRODUCTION}

There are around 89 lagoons ranging from 3 ha to 7,589 ha in extent, of which 8 cover more than 1,000 ha each. The total area of the lagoons is estimated to be about 36,298 ha (CRMP Coastal Habitat Survey, 2002). Lagoons are more abundant along the southern, southeastern and eastern coasts where the littoral drift causes an accumulation of sand to form barriers and spits at river mouths through which the freshwater discharge is low. Sand barrier formation has transformed some basin estuaries into lagoons. Fig. 1 shows the lagoons and estuaries of Sri Lanka.

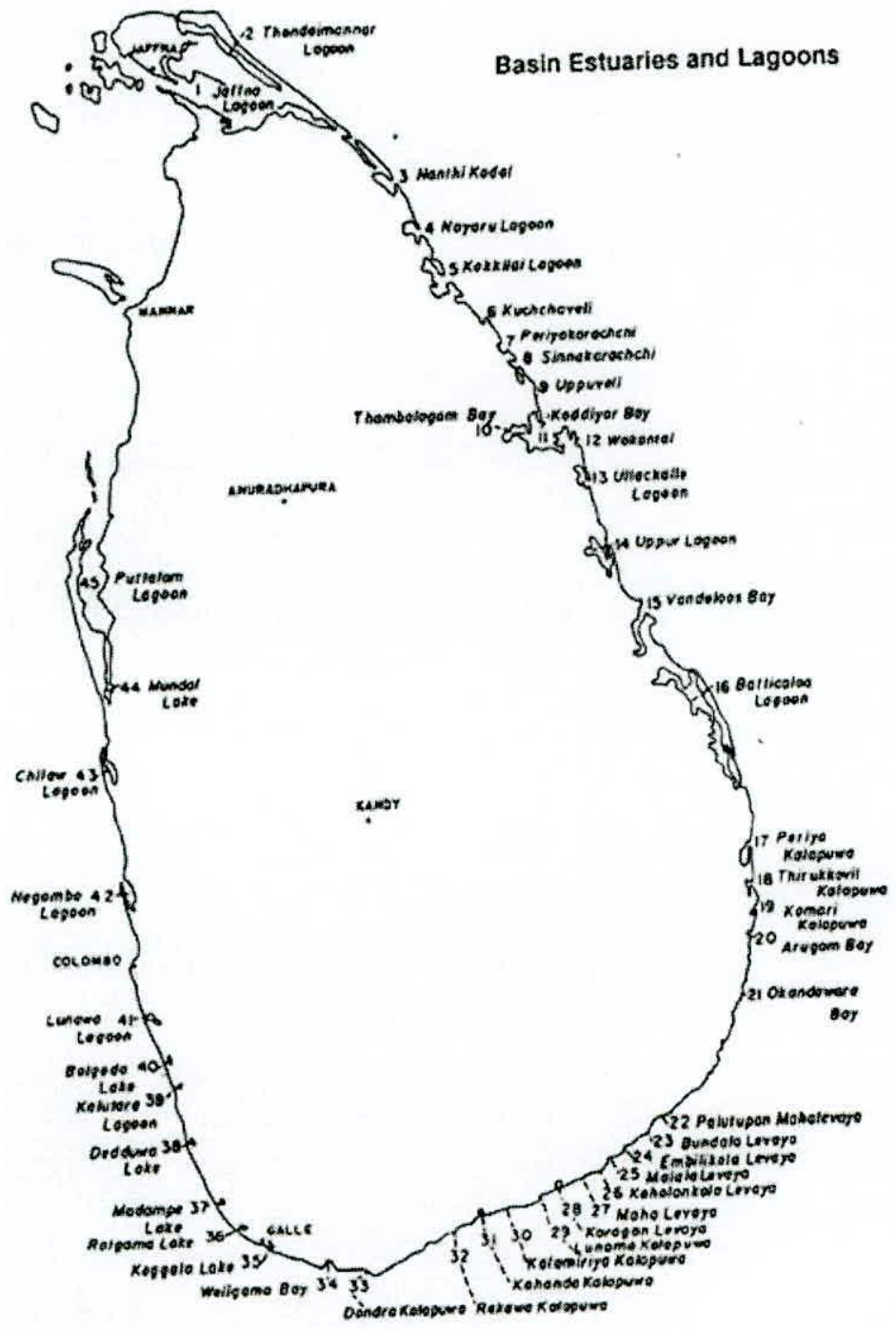

Fig 1: Lagoons and Estuaries of Sri Lanka (Source: NARA) 
The lagoons and estuaries are an interface between marine, freshwater and land, being important coastal environments, which are highly productive due to the fact that they receive high loads of nutrients from lands (DFARD, 1994). But this same fact leads the lagoons and estuaries to suffer due to accumulation of excessive concentrations of organic matter and the subsequent increase in bacterial heterotrophic activities leading to a dramatic consumption of dissolved oxygen (Troussellier, 2007). The oxygen depletion allows reduction of sulfate to hydrogen sulfide which accumulates, provoking a large increase in the mortality of macrofaunal species (Troussellier, 2007). Such dramatic events increase both in frequency and extension as a consequence of eutrophication which is mainly related to the increase in population density and activities in the lagoon watershed. (Troussellier, 2007).

Pollution of Sri Lanka's estuaries and lagoons is extensive in terms of organic load given out by domestic and industrial refuse. Very often household refuse collected by municipalities and Pradeshiya Sabhas is directly dumped into rivers. Coliform bacterial counts often exceed the permitted values. Some examples of highly polluted lagoons and estuaries include; Bolgoda and Negombo estuaries and Lunawa lagoon (Ileperuma, 2000).

\subsection{Physical Features of Lunawa Lagoon}

Lunawa Lagoon is a relatively small lagoon of just over $2 \mathrm{~km}$ in length and an average width of $175 \mathrm{~m}$ located in the Moratuwa-Ratmalana industrial area approximately 14 $\mathrm{km}$ south of Colombo. The lagoon lies in the narrow coastal plain stretching from Dehiwala-Mount Lavinia Municipal Council to the Moratuwa Municipal Council 
(CCD, 2005). (Fig. 2 ). Lunawa lagoon is part of a larger wetland ecosystem with Bolgoda Lake and Attidiya marsh (a bird sanctuary). These three ecosystems which were connected in the past were separated with the construction of the Galle Road.

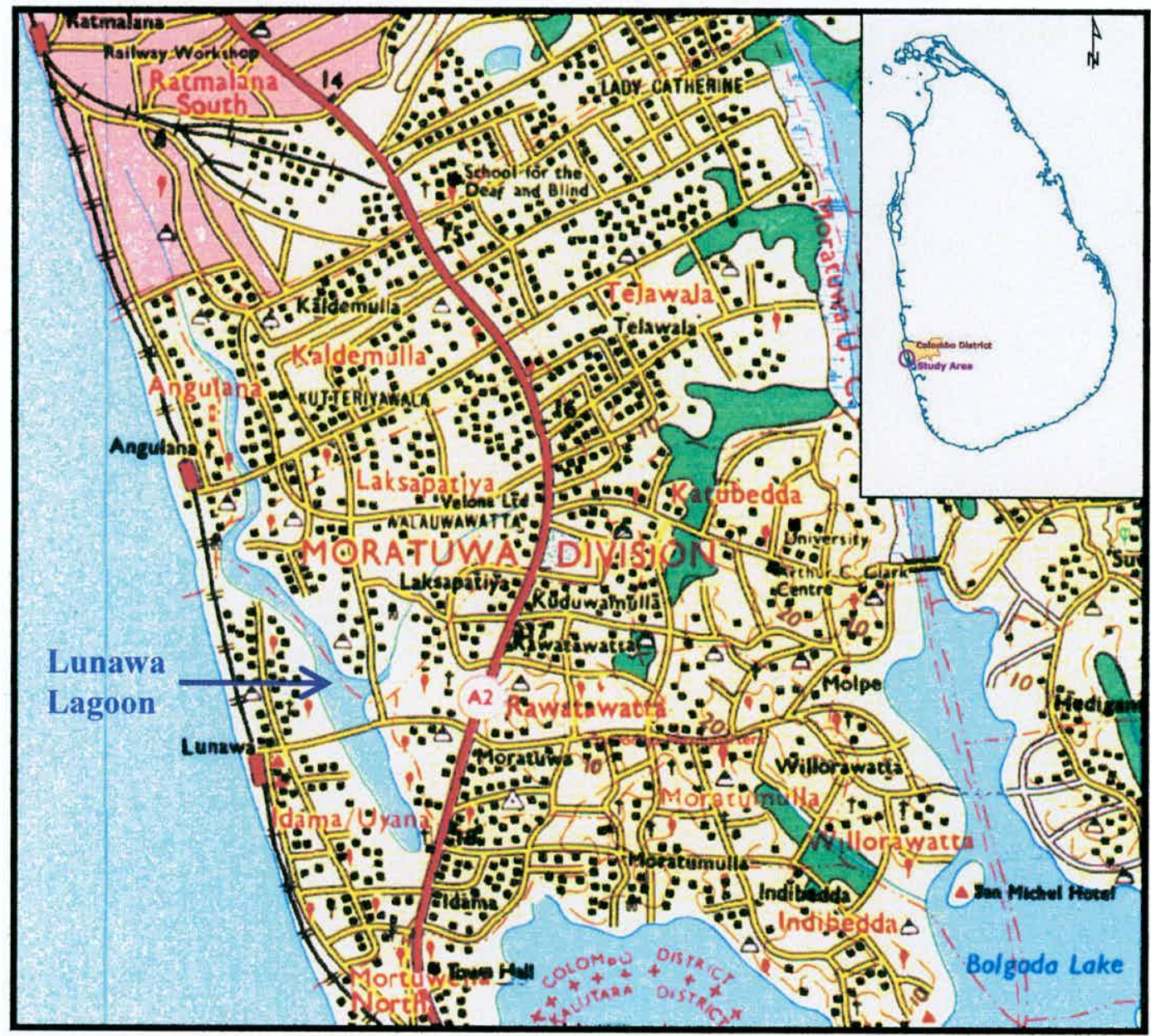

Fig 2. Location of Lunawa Lagoon

The total water surface area of the lagoon is about 40 ha and the highest water level around $1.5 \mathrm{~m}$ above MSL (CCD, 2005). The lagoon is divided into the northern and southern sections by a bridge. The mouth of the lagoon lies on the northwest side of the northern section close to the Angulana Railway Station. The mouth is closed by natural formation of a sand bar preventing exchange of water between the sea and the lagoon and the resultant flushing out of pollutants. The sand bar is occasionally breached manually to minimize floods in the lagoon catchment. Lunawa is one of Sri Lanka's 
true lagoons. The lagoon has no permanent natural water source to sustain itself and depends mainly on surface runoff and discharged water from residential, commercial and industrial sources. There are 3 main tributaries which feed the lagoon, namely: Lunawa Ela (3.8 km in length), Hemingiya Ela $(1.7 \mathrm{~km})$ and Elu Ela $(1.3 \mathrm{~km})(\mathrm{CCD}$, 2005). There are also 3 small municipal drains that discharge effluents to the southeastern and southern parts of the lagoon. The lagoon being part of the Bolgoda basin receives basin discharge through the Bellanwila -Attidiya marshes, thus functioning as a water detention area as well (CCD, 2005).

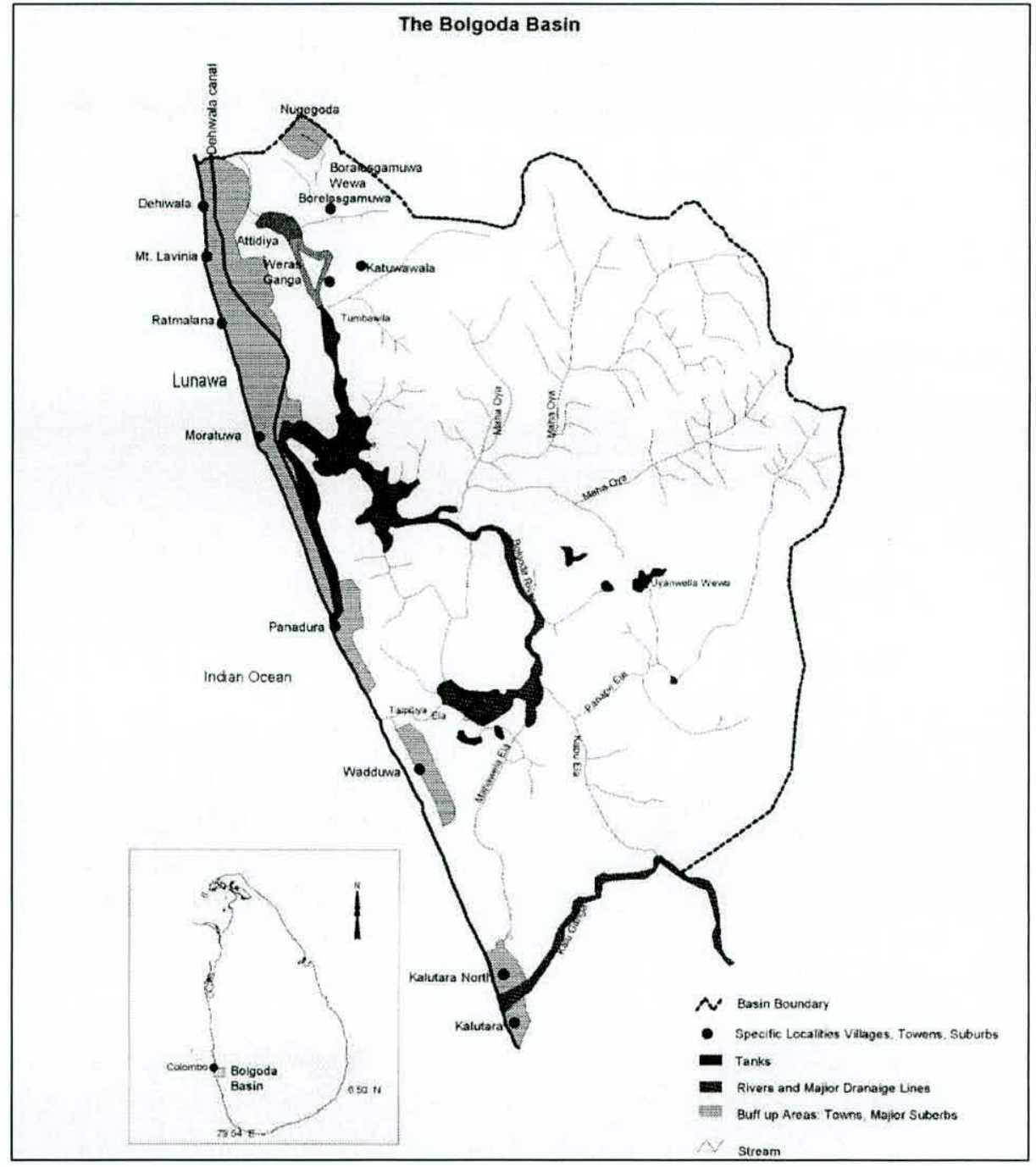

Fig 3:The Bolgoda Basin (Source: CCD,2005) 
A majority of Lunawa lagoon area lies within Moratuwa, which is the heart of the wood industry in Sri Lanka and also a very densely populated city with many saw mills and furniture factories located in the vicinity. A large number of households and industries are present in the lagoon catchment area. The streams entering the lagoon flow from the Dehiwala-Mount Lavinia Municipal Council area which is a very highly industrialized area. According to Dias et al (2004), the major pollution contributor of the Lunawa lagoon is the unmarred discharges of toxic effluents from industries in the Lady Catherine Industrial Estate. Thus, the location of the lagoon has resulted in a very complex environmental situation and interventions.

The lagoon which was once a flourishing ecosystem was known to provide a livelihood for more than 150 fishermen at one time (CCD, 2005). The lagoon was especially famous for its large populations of prawns and fish. The ecological and scenic value presented a recreational amenity. According to reports from locals, a good fishery for "Ahirawa" (Ehirawa fluviatilis) existed in the past (UNESCAP 1985). Fishermen state that they were getting good income daily from fish varieties like "batto"(Tilapia sp), "mal koraliya"(Etroplus suratensis), "Ahirawa", crabs and prawns. Nets and crab traps floating on the surface used to cover the lagoon (Punchihewa 1995). According to NARA (1994), at least 22 fish species and 6 species of crustaceans were recorded with the lagoon being a fishing ground for 150 families before 1979 (Table 1). 